\title{
IMPLIKASI PERGANTIAN ANTAR WAKTU (PAW) ANGGOTA DPRD RIAU TERHADAP ADMINSITRASI PARLEMEN
}

\author{
Hernimawati \\ Universitas Lancang Kuning \\ Email : hernimawati@unilak.ac.id
}

\begin{abstract}
This study examines the dynamics and process of PAW process of six members of DPRD Riau period 20142019 after deciding to become candidate for regional head. The problems that occurred PAW six Riau DPRD members after the enactment of candidates for regional head in the 2015 election did not run in accordance with established procedures. The research used the concept of Alert Time Substitution and Political Representation Theory with qualitative explorative method. The existing information system within the DPRD still does not reflect the regularity of factors that are shaped by the internal political background of political parties. a very long hiatus meeting in Riau's political representation included some neglected agenda and duties of legislation. In addition, the Ministry of Home Affairs decree was abolished in the determination of PAW Riau DPRD members 2014-2019 and became administrative judges that led to the vacancy of parliamentary seats.
\end{abstract}

Keyword: Candidate, DPRD, PAW, Political.

Abstrak

Penelitian ini mengkaji dinamika dan mekanisme proses PAW enam anggota DPRD Riau periode 20142019 pasca ditetapkan menjadi calon kepala daerah. Permasalahan yang terjadi PAW enam anggota DPRD Riau pasca ditetapkannya menjadi calon kepala daerah pada pilkada 2015 tidak berjalan sesuai dengan prosedur yang ditetapkan. Penelitian menggunankan pendekatan konsep Pergantian Antar Waktu dan Teori Perwakilan Politik dengan metode kualitatif eksploratif. Hasilnya menunjukkan bahwa tentang sistem perwakilan politik (representasi politik) dalam kontek PAW anggota DPRD masih belum menunjukkan keteraturan terhadap mekanisme yang ditetantukan melainkan dengan pertimbangan politik pada internal partai politik. terjadinya kekosongan yang begitu lama dalam perwakilan politik di parlemen Riau menyebabkan beberapa agenda dan tugas-tugas legislasi terabaikan. Selain itu keterlambatan SK Kemendagri dalam penetapan PAW anggota DPRD Riau 2014-2019 juga menjadi kendala adminsitratif yang menyebabkan kekosongan kursi parlemen.

Keyword: Calon, DPRD, PAW, Politik.

\section{PENDAHULUAN}

Penggantian Antar Waktu (PAW) terjadi pada anggota DPRD Riau periode 20014-2019 pasca penetapan enam anggota DPRD Riau menjadi calon kepala daerah pada pilkada desember 2015. Adapaun enam anggota DPRD Riau tersebut yaitu Suparman dan Indra Putra dari Farksi Partai Golkar, Mursini dari PPP, Eko Soehardjo dari Partai Demokrat, dan Zukri Misran dan Syafrudin Potti dari PDIP. PAW enam anggota DPRD Riau tersebut melalui mekanisme yang panjang dan menimbulkan berbagai polemik baik ditingkat elit maupun pada masyarakat. Mulai dari tahap pengusulan pemberhentian oleh dewan perwakilan daerah (DPD) provinsi partai politik, persetujuan dalam rapat DPRD, ferivikasi KPUD Provinsi Riau, surat pengusulan yang kemudian diteruskan ke mendagri untuk dikeluarkan peresmian penggantian antar waktu melalui gubernur (Pasal 385/ Pasal 388 Undang-undang Nomor 27 Tahun 2009 Junto Pasal 104/ Pasal 107 Peraturan Pemerintah Nomor 16 tahun 2010). 
Pemberhentian dan pengangkatan PAW anggota DPRD ditetapkan dengan keputusan Gubernur atas nama presiden. Kemudian diatur lagi dalam Pasal 16 ayat (2) Kepmendagri Nomor 13 Tahun 2000 tentang Pedoman Penggantian Antar Waktu yang menegaskan anggota DPRD Provinsi pengganti antar waktu diresmikan secara administrasi dengan keputusan mendagri atas nama presiden. Realitasnya, masih ada celah yang menjadi perdebatan dalam mekanisme PAW anggota DPRD Riau yang ditetapkan oleh KPUD menjadi calon kepala daerah. Mulai dari terlambatnya surat keputusan mendagri terkait penetapan pengganti PAW dari keenam anggota DPRD Riau yang ikut pilkada lalu Partai PDIP yang belum mengajukan nama untuk pengganti Zukri Misran dan Syaifudin Potti. Implikasinya terjadi kekosongan perwakilan didaerah pemilihan enam anggota dewan yang mengundurkan diri tersebut. Secara administrasi sangat berpengaruh terhadap DPRD Riau dalam pengambilan keputusan dan bagi masyarakat daerah pemilihan dalam menyampaikan aspirasinya kepada pemerintah. Penelitian ini diharapkan dapat menjadi peningkatan pemahaman dan pengembangan studi tentang sistem perwakilan politik (representasi politik) dalam kontek PAW anggota DPRD. memberikan kontribusi kepada Pemerintah, DPRD, KPUD, dan Partai Politik dalam mengambil keputusan yang efektif terkait proses PAW anggota DPRD agar tidak terjadi kekosongan yang begitu lama dalam perwakilan politik di daerah.

\section{METODE}

Penelitian ini menggunakan pendekatan kualitatif dengan cara studi, melalui tipe ekploratif. Pendekatan dan desain penelitian diatas adalah untuk menggambarkan tentang bagaimana Dinamika Pergantian Antar Waktu (PAW) enam anggota DPRD Riau Pasca Penetapan Menjadi Pasangan Kepala Daerah Pada Pilkada 2015 oleh KPUD Riau. Penelitian ini akan dilakukan pada DPRD Provinsi Riau, KPUD Provinsi Riau, dan DPD Partai Politik dari enam anggota DPRD yang mengundurkan diri. Lembaga tersebut memiliki kewenangan dalam memproses PAW anggota DPRD Riau periode 2014-2019. Adapun alasan pemilihan ketiga lembaga tersebut karena mekanisme proses PAW anggota DPRD sangat ditentukan oleh keputusan yang diambil oleh ketiga lembaga sehingga tidak terjadi kekosongan dalam perwakilan politik di daerah.

Informan merupakan orang yang dimanfaatkan untuk memberikan informasi tentang situasi dan kondisi latar belakang penelitian (Moleong, 2004: 135). Dalam penelitian ini peneliti menggunakan teknik purposive sampling yakni, teknik pengambilan sampel sumber data dengan pertimbangan tertentu. Penggunaan teknik purposive sampling dimaksudkan untuk mengambil sejumlah orang yang dipilih oleh peneliti menurut kriteria yang dimiliki oleh orang tersebut. Dengan kata lain informan dipilih dengan cermat sehingga relevan dan cukup representatif dengan desain penelitian. Informan yang dimaksudkan dalam penelitian ini adalah orang-orang yang terlibat dalam penelitian yang akan memberikan informasi atau jawaban mengenai apa yang menjadi objek penelitian.

Dalam penelitian ini informan yang dipilih berdasarkan kriteria sebagai berikut:

Tabel 2. Daftar Nama Informan

\begin{tabular}{|l|c|c|}
\hline No & Nama Informan & Jabatan \\
\hline 1 & Indra Putra, ST & Fraksi Golkar \\
\hline 2 & Yulisman, S.Si & Fraksi Golkar (PAW) \\
\hline 3 & Suparman, S.Sos & Fraksi Golkar \\
\hline 4 & Masgaul Yunus, SH, MH & Fraksi Golkar (PAW) \\
\hline 5 & Zukri Misran & Fraksi PDIP \\
\hline 6 & Syaifuddin Potti & Fraksi PDIP \\
\hline 7 & Eko Suhardjo, SH & Fraksi Demokrat \\
\hline 8 & H. Muhammad Yatim, SE & Fraksi Demokrat \\
\hline 9 & Mursini & Fraksi PPP \\
\hline 10 & Malik Siregar & Fraksi PPP \\
\hline 11 & Ilham M Yasir, SH, LLM & KPUD Riau Divisi Hukum \\
\hline
\end{tabular}




\begin{tabular}{|l|c|c|}
\hline 12 & Abdul Hamid, SP, M.Si & KPUD Riau Divisi Teknis \\
\hline 13 & Kordias Pasaribu & Ketua DPD PDI-P Riau \\
\hline
\end{tabular}

\section{HASIL DAN PEMBAHASAN}

\subsection{Mekanisme PAW Enam Anggota DPRD Riau Periode 2014-2019}

Pergantian Antar Waktu (PAW) enam anggota DPRD Riau yang maju pada Pilkada serentak Desember 2015 melalui dinamika dan proses yang cukup panjang. Seperti diketahui bahwa ada enam anggota DPRD Riau yang maju pada Pemilihan Kepala Daerah (Pilkada) serentak 9 Desember 2015. Sesuai dengan keputusan Mahkamah Konstitusi (MK) bahwa anggota DPRD yang maju Pilkada harus mengundurkan diri. Enam Anggota DPRD Riau tersebut berasal dari beberapa partai politik peserta Pileg 2014, diantaranya Suparman (Golkar), Indra Putra (Golkar), Syafaruddin Poti (PDIP), Zukri Misran (PDIP), Eko Suharjo (Demokrat), dan Mursini (PPP).

Namun, jika mengacu pada peraturan nama-nama PAW enam anggota DPRD tersebut bisa dilihat seperti dalam sistem informasi pergantian antar waktu (Simpaw) dari KPU. Dimana KPU menerima usulan PAW melalui surat yang disampaikan oleh Ketua DPRD, selanjutnya KPUD Riau memproses dalam waktu lima hari kerja. KPUD Riau melakukan rapat dan sidang pleno untuk menentukan siapa PAW dari enam anggota DPRD yang mengundurkan diri tersebut (Abdul Hamid, 15 Mei 2016).

Ketentuan pengganti PAW yaitu sebagaimana legislator yang diganti merupakan perolehan suara terbanyak setelah legislator yang digantikan. Dengan demikian nama-nama tersebut bisa dilihat dari hasil Pemilihan Legislatif (Pileg) tahun 2014 lalu. Berdasarkan data Pileg 2014 yang diperoleh dari Komisi Pemilihan Umum (KPU) Provinsi Riau nama-nama tersebut di antaranya Suparman yang mencalonkan diri sebagai Bupati Rokan Hulu, terpilih saat Pileg 2014 dengan 25.110 suara, akan digantikan oleh Masgaul Yunus SH MH dengan perolehan suara terbanyak kedua yakni 8.089 suara. Kemudian, Syafarudin Poti, yang juga maju sebagai calon Bupati Rokan Hulu, pada Pileg 2014 lalu memperoleh 14.952 suara, akan digantikan oleh Rusli Ahmad, yang memperoleh suara sebanyak 6.536. Selanjutnya Indra Putra yang maju sebagai Bupati Kuansing, memperoleh suara sebanyak 17.448, akan digantikan oleh Yulisman, dengan prolehan suara sebanyak 10.708 (Sekretariat KPUD Riau 2016).

Selanjutnya Mursini yang maju sebagai calon Bupati Kuansing, memperoleh 14.471 suara saat Pileg lalu, akan digantikan Malik Siregar yang hanya memperoleh suara sebanyak 1.909. Kemudian Zukri Misran yang memperoleh suara sebanyak 31.034, akan digantikan oleh Ev. Tengger Sinaga yang memperoleh suara sebanyak 10.245. Selanjutnya Eko Suharjo, yang maju sebagai Wakil Walikota Dumai mendampingi Zulkifli As, saat Pileg 2014 memperoleh suara sebanyak 13.462, akan digantikan oleh Edi Muhammad Yatim, yang memperoleh suara sebanyak 4.374.

PDI-Perjuangan membenarkan jika pengganti Zukri Misran merupakan Tengger Sinaga dan Pengganti Syafruddin Poti merupakan Rusli Ahmad. Untuk Pelalawan PDI Perjuangan dapat dua suara yakni, Zukri dan dibawahnya Soniwati. Kemudian suara selanjutnya Tengger sinaga, sehingga saudara Tengger Sinaga yang akan menggantikan Zukri. Kemudian untuk pengganti Syafruddin Poti di Kabupaten Rokan Hulu adalah Rusli Ahmad (Ketua DPD PDI-Perjuangan Riau, Kordias Pasaribu). Pimpinan DPW PPP juga membenarkan jika pengganti Mursini yang maju pada Pilkada di Kabupaten Kunsing akan digantikan oleh Malik Siregar. Untuk PAW itu kan sudah ada peraturanya siapa yang memperoleh suara terbanyak berikutnya. Kecuali yang bersangkutan dalam persoalan hukum atau hal lainya. Kalau untuk pengganti Pak Mursini itu adalah Malik Siregar (Wakil Ketua DPW PPP Riau, Husaimi Hamidi).

Terka proses PAW di KPU Provinsi Riau, dengan melakukan verifikasi data calon yang akan menggantikan anggota DPRD Riau yang maju pada Pilkada 2015. Penggantian tersebut berdasarkan perolehan suara terbanyak atau perolehan suara nomor dua dibawah anggota dewan yang mundur. Mekanismenya, partai mengajukan pengunduran diri anggota dan menunjuk anggota baru untuk mengisi PAW kepada pimpinan DPRD Riau. Pimpinan dewan kemudian akan menelaah bersama Badan Kehormatan DPRD Riau untuk selanjutnya meneruskan ke KPU Riau (Ilham M Yasir). Pada dasarnya enam nama 
anggota DPRD Riau yang maju Pilkada desember 2015 tersebut sudah melalui proses Paripurna di DPRD Riau untuk diusulkan pemberhentiannya secara resmi kepada Kementrian Dalam Negeri melalui pemerintah provinsi Riau, akan tetapi dari keputusan Mendagri dua nama yang diusulkan tidak disetujui. Lebih lanjutnya berikut skema proses PAW enam anggota DPRD Riau 2014-2019 yang maju dalam Pilkada Desember 2015.

1.2. Problematika PAW Enam Anggota DPRD Riau Periode 2014-2019

1. Konsistensi Partai dalam Memproses Usulan PAW

Permaslahan Pergantian Antar Waktu (PAW) dua anggota DPRD Riau dari fraksi PDI P belum dapat dilaksanakan. Meskipun persoalan tersangkut pada permasalahan di DPP, Fraksi PDIP DPRD Riau memastikan proses PAW tersebut tinggal hanya menunggu persiapan kelengkapan administrasi. Demikian disampaikan ketua fraksi PDI P DPRD Riau, Makmun Solihin, Rabu (10/2/2016) di gedung DPRD. Prosesnya udah hampir selesai. Kekosongan dua kader PDI P dalam struktur di DPRD Riau telah melemahkan dan memengaruhi kinerja pihaknya di lembaga legislatif tersebut.

Namun begitu, pihaknya juga dapat memaklumi kepentingan DPP partai yang lebih memprioritaskan untuk fokus memenangkan partai berlambang banteng ini di Kalimantan Tengah dalam pemilihan Gubernur yang sempat bermasalah. DPP PDI-P sekarang tengah sibuk menyelesaikan persoalan pemenangan partai di Kalteng. Kita masih menunggu hingga akhirnya DPP dapat menentukan figur PAW DPRD Riau sesegera mungkin. Diketahui sebelumnya, proses peralihan dua PAW PDI P DPRD Riau saat ini masih terkesan mandeg dan jalan di tempat. Padahal dari enam anggota DPRD Riau yang maju di Pilkada 2015 lalu, sudah ada empat yang telah di PAW dan dilantik beberapa waktu lalu. Jadi, hanya tinggal pengganti Zukri Misran dan Safruddin Poti dari PDIP saja yang belum ditetapkan. Dapat dipetakan tigkat konsistensi partai politik masih sangat rendah terkait proses PAW yang sedang berlangsung. Penelitipun mengintrepretasikan partai yang konsisten dan tidak konsisten sperti tabel dibawah ini.

Tabel 3 . PAW Anggota DPRD Riau 2014-2016

\begin{tabular}{|l|c|l|l|l|}
\hline No & Nama Anggota DPRD & PAW & Partai Politik & Ket \\
\hline 1. & Suparman & Masgaul Yunus & Golkar & $\begin{array}{l}\text { Konsisten } \\
\text { Tetap dilantik }\end{array}$ \\
\hline 2. & Indra Putra & Yulisman & Golkar & $\begin{array}{l}\text { Konsisten } \\
\text { Tetap dilantik }\end{array}$ \\
\hline 3. & Mursini & Malik Siregar & PPP & $\begin{array}{l}\text { Konsisten } \\
\text { Tetap dilantik }\end{array}$ \\
\hline 4. & Eko Suharjo & $\begin{array}{l}\text { Edi Muhammad } \\
\text { Yatim }\end{array}$ & P Demokrat & $\begin{array}{l}\text { Konsisten } \\
\text { Tetap dilantik }\end{array}$ \\
\hline 5. & Zukri Misran & Tengger Sinaga & PDI-P & Tidak Dilantik \\
\hline 6. & Safruddin Poti & Rusli Ahmad & PDI-P & Tidak Dilantik \\
\hline
\end{tabular}

Sumber: data olahan penelitian 2016

\section{Mekanisme Internal Partai Dalam Proses PAW}

Ke enam Anggota DPRD Riau Periode 2014-2019 berhenti antar waktu karena mengundurkan diri dan maju dalam pilkada 2016. Artinya DPRD Riau diberhentikan antar waktu karena tidak dapat melaksanakan tugas secara berkelanjutan atau berhalangan tetap sebagai anggota DPRD Riau. Maka diusulkan oleh partai politiknya sesuai dengan ketentuan peraturan perundang-undangan tidak lagi memenuhi syarat sebagai calon anggota DPRD Riau sesuai dengan ketentuan peraturan perundang-undangan mengenai pemilihan umum.

Pemberhentian anggota DPRD Riau karena mengundurkan diri, dan diberhentikan, selanjutnya diusulkan oleh pimpinan partai politik kepada pimpinan DPRD Riau dengan tembusan kepada gubernur. Paling lama tujuh hari sejak diterimanya usulan pemberhentian sebagaimana dimaksud pimpinan DPRD menyampaikaan usulan pemberhentian anggota DPRD Riau kepada gubernur untuk memperoleh peresmian pemberhentian. Paling lama tujuh hari sejak diterimanya usulan pemberhentian sebagaimana dimaksud menyampaikan usulan tersebut kepada gubernur. Gubernur meresmikan pemberhentian paling lama empat belas hari sejak 
diterimanaya usulan pemberhentian anggota DPRD Riau. Pemberhentian anggota DPRD Riau sebagaimana dimaksud dilakukan setelah adanya hasil penyelidikan dan verifikasi yang dituangkan dalam keputusan Badan Kehormatan DPRD kabupaten/kota atas pengaduan dari pimpinan DPRD , masyarakat dan atau pemilih. Keputusan Badan Kehormatan (BK) DPRD mengenai pemberhentian anggota DPRD Riau sebagaimana dimaksud dilaporkan oleh BK kepada Rapat Paripurna.

Paling lama tujuh hari sejak keputusan BK DPRD Riau yang telah dilaporkan dalam Rapat Paripurna, pimpinan DPRD menyampaikan keputusan Badan Kehormatan tersebut kepada pimpinan partai politik yang bersangkutan. Pimpinan partai politik yang bersangkutan menyampaikan keputusan pemberhentian anggotanya kepada pimpinan DPRD paling lambat tiga puluh hari sejak diterimanya keputusan Badan Kehormatan DPRD kabupaten/kota dari pimpinan DPRD.

Dalam hal pimpinan partai politik sebagaimana dimaksud tidak memberikan keputusan pemberhentian sebagaimana dimaksud pimpinan DPRD, tetapi meneruskan keputusan BK DPRD kepada Gubernur untuk memperoleh peresmian pemberhentian. Paling lama tujuh hari sejak diterimanya keputusan pemberhentian sebagaimana dimaksud. Paling lambat empat belas hari sejak menerima nama anggota DPRD yang diberhentikan dan nama calon pengganti antar waktu, dari gubernur meresmikan pemberhentian dan pengangkatan dengan keputusan gubernur. Sebelum memangku jabatan anggota DPRD pengganti antar waktu mengucapkan sumpah/janji yang pengucapannya dipandu oleh pimpinan DPRD kabupaten/kota.

Rangkaian panjang proses tersebut memberikan gambaran PAW anggota DPRD bukanlah sesuatu yang mudah tetapi melalui proses administrasi sehingga cukup memakan waktu. Selanjutnya mekanisme internal partai juga menjadi sesuatu pertimbangan yang memakan waktu panjang. Walaupun secara proses partai mengsulkan nama yang diberhentikan akan tetapi nama yang menggantikan (PAW) yang menjadi proses yang panjang dipartai politik. Kepengurusan partai politik harus memahami dan arif terkait pergantian di DPRD, karena kalau dibiarkan terus seperti ini akan mengganggu proses pengambailan keputusan di organisasi DPRD Riau itu sendiri.

Salah satu yang menjadi kendala administratif yaitu lamanya surat keputusan (SK) resmi dari Kementrian dalam Negeri (Kemendagri) terkait enam anggota DPRD yang di PAW. Pada tanggal 21 Desember 2015 akhirnya dikeluarkannya 4 SK Mendagri Republik Indonesia yakni sebagai berikut,

a. SK Mendagri dengan No Surat I61.H-6026 tanggal 23 November 2015 Tentang Peresmian Pengangkatan Masgaul Yunus, SH, MH dari Partai Golkar se $\neg$ bagai PAW anggota DPRD Riau Sisa Masa Jabatan Tahun 2014-2019 terhitung mulai tanggal Pengu-capan Sumpah/Janji.

b. SK Mendagri dengan No Surat 161.14-6027 tanggal 23 November 2015 Tentang Peresmian Pengangkatan Malik Siregar dari PPP sebagai PAW Anggota DPRD Provinsi Riau Sisa Masa Jabatan Tahun 2014-2019 ter-hitung mulai tanggal Penguาcapan Sumpah/janji.

c. SK Mendagri dengan No Surat 161.14-6028 tanggal 23 November 2015 Tentang Pere $\neg$ smian Pengangkatan Saudara Eddy A. Mohd Yatim, SE dari Partai Demokrat sebagai PAW Ang $g$ gota DPRD Riau sisa Masa Jabatan Tahun 2014-2019 terhitung mulai tanggal Pengucapan Sumpah/janji.

d. SK Mendagri dengan No Surat 161.14-6043 tanggal 23 November 2015 Tentang Peresmian Pengangkatan Saudara Yulisman, S.Si dari Partai Golkar sebagai PAW Anggota DPRD Riau sisa Masa Jabatan Tahun 2014-2019 terhitung mulai tanggal Pengucapan Sumpah/janji

Namun yang menarik disini adalah tidak tercantumnya Surat Keputusan Kemendagri terkait PAW dua kader PDI-P. Titik inilah yang menjadi permasalahan administratif dimana PDI-P sebagai partai pemerintah justru memperlambat mekanisme PAW bagi kadernya sendiri, bukan mempercepat proses administrasi PAW itu sendiri. Seharusnya PDIP mampu menjadi contoh dalam proses pelaksanaan mekanisme PAW yang sesuai dengan amanat dari peraturan yang berlaku. Berdasarkan temuan analisis wawancara dan data di media sebagai arsip pendukung, peneliti meintrepretasikan keterlambatan proses PAW enam anggota DPRD Riau pasca ditetapkannya menjadi calon kepala daerah dalam pilkada desember 2015 sesungguhnya dari internal 
PDIP sebagai partai pemerintah, namum berimplikasi terhadap partai politik lainnya yang kadernya juga di PAW.

\section{KESIMPULAN}

Kesimpulannya bahwa dinamika pergantian antar waktu (PAW) enam anggota DPRD Riau melalui proses dan dinamika yang cukup panjang. Hal tersebut berimplikasi terhadap terhambatnya prosedur PAW sebagaimana yang telah ditetapkan oleh peraturan UU yaitu melebihi 60 hari bahkan sampai pada 120 hari pasca mengundurkan diri. Permasalahannya yang terjadi diantaranya rendahnya konsistensi partai dalam memproses usulan PAW, mekanisme internal partai yang dalam usulan PAW terjadi banyak perdebatan dan banyak pertimbangan, selanjutnya lambatnya SK Mendagri dalam memutuskan PAW terhadap enam anggota DPRD Riau tersebut berdampak kelengkapan administrasi parlemen dan kinerja DPRD Riau dalam melaksanakan tugas budgeting, regulasi dan pengawasan.

\section{DAFTAR PUSTAKA}

[1]. Budiarjo, Miriam. 2008. Dasar-Dasar Ilmu Politik. Jakarta: PT. Gramedia Pustaka Utama

[2]. Creswell, John. W. Research Design, Qualitative and Quantitative Aproaches, Jakarta : KIK Press.

[3]. Faisal, Sanafiah. 1990. Penelitian Kualitatif: Dasar-dasar dan Aplikasi, Malang: YA3 Malang.

[4]. Gaffar, Affan. 2000. Politik Indonesia: Transisi Menuju Demokrasi. Yogyakarta: Pustaka Pelajar

[5]. J. Moleong, Lexi. 2005. Metode Penelitian Kualitatif. Bandung : PT. Remaja Rosdakarya.

[6]. Marbun, BN. 2005. Kamus Politik. Jakarta: Pustaka Sinar Harapan

[7]. Nimmo, Dan. 2004. Komunikasi Politik. Bandung: PT. Remaja Rosdakarya. 1

[8]. Pamungkas, Sigit. 2012. Partai Politik: Teori dan Praktik di Indonesia. Yogyakarta: Institute for democracy and welfarism

[9]. Purwanto, Edi, Demokratisasi, Sistem Politik dan Pemerintahan, Averroes Press, Malang, 2011.

[10]. Syaukani, Afan Gafar, M. Ryaas Rasyid,.2002. Otonomi Daerah Dalam Negara Kesatuan. Yogyakarta: Pustaka Pelajar.

[11]. Solihin, Dadang. Pengukuran Good Governance Index - Bahan Diskusi Evaluasi Kemampuan Penyelenggaraan Otonomi daerah (EKPOD) - Jakarta: Direktorat Jenderal Otonomi daerah, Depdagri.

[12]. K. Yin, Robert. 2003. Studi Kasus (Desain dan Metode), Jakarta : PT. Raja Grafindo Persada.

[13]. Jimly Asshiddiqie, Desember 2006, "Partai Politik dan Pemilihan Umum Sebagai Instrument Demokrasi” Jurnal Konstitusi, Volume 3 Nomor 4. 
[14]. Sebastian Salang, Parlemen: Antara Kepentingan Politik VS Aspirasi Rakyat, Dalam Jurnal Konstitusi, Volume 3 Nomor 4, Desember 2006.

[15]. Yandra, A. (2017). Fisibilitas Pilkada Serentak Tahap II Kota Pekanbaru Pasca Permendagri No 18 Tahun 2015. Jurnal Niara, 9(2), 62-74.

[16]. Undang-undang Nomor 27 Tahun 2009

[17]. Peraturan Pemerintah Nomor 16 tahun 2010

[18]. http://legislasi.blogspot.com/2008/12/konsep-legislasi.html

[19]. http://www.negarahukum.com/hukum/penggantian-antar-waktu-paw.html 